\title{
KÖNYVISMERTETŐ
}

\section{Elveszett illúziók: A világgazdaság tartós válságáról}

\author{
MTA Közgazdaság-és Regionális \\ Tudományi Kutatóközpontja \\ Világgazdasági Intézet, Budapest, \\ 2012. 312 oldal \\ Szerkesztette: \\ Farkas Péter - Meisel Sándor - \\ - Weiner Csaba
}

Az immáron negyedik éve tartó világgazdasági válság alapvetően meghatározza az országok mozgásterét is, ezért szükséges a válság mibenlétének, a kialakuláshoz vezető okoknak, a politikai és társadalmi következményeknek, a válságkezelés módozatainak és mindezek magyar gazdaságra gyakorolt hatásainak a vizsgálata. Olvasható a most már hosszú nevú Intézet legújabb tanulmánykötetében. (Az már csak a sors vagy ki tudja minek és kinek a fintora, hogy az Akadémia éppen mostanában tartotta fontosnak a korábban önálló Világgazdasági Kutatóintézet státusának módosítását.)

De visszatérve a világgazdasághoz, akármilyen szomorú is, de eddig a válságkezelés egyetlen országban sem járt sikerrel, köztük Magyarországon sem. Hogyan lehetséges, hogy több évvel a válság kitörés óta nincs egyértelmú elemzés arról, hogy mi vezetett a válsághoz, sem arról, hogy miként lehetne belôle kilábolni - tette fel a kérdést nemrég egy napilapcikk szerzője. Majd folytatta a spanyol példa alapján - mely azonban nemcsak az ibériai országra vonatkoztatható - ,mekkora a része ebben a spanyol politikai elitnek, amely... azzal foglalatoskodott, hogy kiiktatta a valódi fékeket a rendszerból, politikai zsákmánynak tekintette az alkotmánybíróságot, a nemzeti bankot, a tőzsde- felügyeletet és legfóbb bírói hatalmat, az összes olyan intézményt, amely ellenórizhette volna a hatalmat" (Népszabadság, 2012. október 13.).

A Világgazdasági Intézet kötetének tanulmányai más-más nézőpontból próbálnak erre a kérdésre választ adni. Simai Mihály akadémikus a 2012. évi davosi világkonferencia előadásainak és vitáinak alapján jut arra a következtetésre, hogy néhány óriásvállalat vezetőinek kivételével, amelyek viszonylag sikeresen konszolidálták helyzetüket, az általános borúlátás volt a jellemzô a gazdasági és politikai vezetôk rendszeres évi találkozójára. Ezt fejezte ki a 2012. évi Világgazdasági Fórum címszava is „Great Transformation”, azaz a „nagy átalakulás”. De ennek irányai már kevésbé világosak. A szerző a XXI. századi globális kapitalizmus fontos vonásaként emeli ki azt a társadalmi változást - és ez Magyarországra is érvényes -, hogy a népesség három csoportra oszlik, azokra, akik a globalizálódó rendszer részei, azokra, akik ebból tartósan kimaradnak és azokra, akik a közbeesók, elóbb-utóbb egyik vagy másik csoporthoz csapodnak. Egy másik fontos fejlemény Simai szerint a nagy multinacionális nemzetközi társaságok térnyerése. A XXI században nincs még egy olyan intézmény, amely e társaságokhoz hasonló szerepet játszana a világgazdaság fejlődésében, a piaci érdek- és értékviszonyok globális terjedésében. A szerző következtetései nem optimiság, kiszámíthatatlanság jellemezheti. Ezek adódhatnak a makroszintű egyensúlyi zavarokból, a gazdaságilag törékeny államok számának növekedéséból, valamint a környezeti - víz-élelem-energia - tényezókbool.

A világgazdasági válság okaival részletesebben foglalkozik Farkas Péter tanulmánya, aki szerint bár a mélyebb világgazdasági válságot és a megrendítô értékvesztést az állami mentőcsoma- gok révén egyelőre sikerült megakadályozni, de ennek súlyos ára is volt. Nem mentek végbe, vagy csak kismértékben zajlottak le azok a szerkezeti változások, amelyek a válság során általában végbemennek. Rizikótényezókként a szerző a nemzetközi pénzügyi rendszer bizonytalanságait, a reálgazdasági túl kapacitásokat, valamint egyes országok fizetési nehézségeit, illetve ennek okait jelöli meg.

Három ezt követô tanulmány az állami szerepvállalással (Körösi István), a bankszabályozás problémáival (Biedermann Zsuzsanna) és a világkereskedelem alakulásával (Kiss Judit) foglalkozik. Inotai András Válaszúton az Európai Integráció címú tanulmányában két kérdést tárgyal: elôször az uniós válságkezelés eredményeit, a gazdaságpolitikai kihívásokat öszszegzi, majd az euró lehetséges jövőjét veszi górcsô alá. Az Unió jelenlegi alapvető feladatát a szerző a válságkezelés költségeinek a kezelésében látja. A legrosszabb forgatókönyvet a széles körú állami beavatkozással ugyan az Európai Unió elkerülte, de ennek ára, az államadóság és a költségvetési hiány gyors növekedése volt. A költségvetési konszolidáció minden országban elkerülhetetlen, de a fiskális konszolidációt össze kell egyeztetni a gazdasági növekedéssel. A szerzô állítja, hogy az államadóság részleges elinflálása elkerülhetetlen. Nem vitatja, hogy az infláció elsôsorban a társadalom szegényebb rétegeit sújtja, de szerinte ezt a káros hatást enyhíteni lehet. Számomra kérdés, hogy a szerző által javasolt megoldás, a társadalmi párbeszéd, ez ügyben hozhat-e megoldást. Fontos megállapítása Inotai Andrásnak, hogy a válság tette nyilvánvalóvá az üzleti szektor és a közvélemény válságkezeléssel kapcsolatos nézetkülönbségét. Míg az üzleti szektor nyitott maradt, és tartózkodott a protekcionista lépé- 
sektôl, addig az európai társadalmak nagyobb része befelé fordult. Nagy kérdés, hogy az Unió vezetôi és polgárai hogyan mozgósíthatók, miként nézhetnek szembe a XXI század kihívásaival. A szerző válasza érdekes: azt kell bemutatni, hogy mi az ára a ,nem Európának?

A mintegy félmilliárd európai polgár számára az Unió küldetését kellene világosan meghatározni, ez az új minőség a nemzeti költségvetések eddiginél nagyobb „közösségesítését” jelentené, sokszorosát a jelenlegi bruttó nemzeti jövedelem erôsen vitatott egy százalékának. Továbbá a nemzetállamok készségét arra, hogy feladják nemzeti szuverenitásuk további jelentős részét. Sajnos, és ez már a recenzens véleménye, ez nem látszik manapság reális célnak.

Az Artner Annamária - Róna Péter szerzôpáros az optimális valutaövezet, Rácz Margit az eurózóna adósságvál- ságával foglalkozik. Utóbbi tanulmány statisztikai adatok sokaságával mutatja be, hogy a reálgazdasági teljesítmények szempontjából meghatározó az élő és holt munkaráfordítások, a munkanélküliség és a beruházások alakulása. Különösen figyelemre méltó ebból a szempontból a német gazdaság, ahol a 2008 és 2012 között mindössze egyetlen évben, 2009-ben csökkentek a beruházások.

Három országtanulmányt követően (Olaszországról, Somai Miklós), Portugáliáról és Spanyolországról (Éltető Andrea) Válság és válságkezelés a visegrádi országokban címmel Novák Tamás elemzését olvashatjuk. Kezdetben inkább csak az ütemezésben mutatkoztak különbségek a visegrádi négyek között, a fő lépések mindenhol: privatizáció, FDI-bevonás és esetenként, a liberalizáció. 2004-tôl, az EUcsatlakozástól, azonban felerôsödtek a divergens folyamatok. Ennek jelei a szlovák GMU-tagság, illetve a magyar gazdaság leszakadása a három másik országtól. Ez a különbség eltérô válságkezelési lehetôségeket és eszközöket kínált, ami a gazdasági fejlődés trendjeiben tovább mélyítette a szakadékot Magyarország és a másik három ország között. Ez különösen élesen mutatkozott meg a beruházások alakulásában, 2008-tól minden évben Magyarországon volt a legalacsonyabb a bruttó beruházások GDP-hez mért aránya.

A tanulmánykötet három utolsó tagja Meisel Sándor értekezése a balti országok gazdaságáról, Ludvig Zsuzsa írása posztszovjet térségrôl és Szigetvári Tamás elemzése az arab világ gazdaságairól.

A 14 tanulmányt a munkaközösség a fiatalon elhunyt Fóti Gábornak ajánlotta, aki több évtizeden keresztül szerkesztette az Intézet kiadványait.

Becsky Róbert

\section{Bőgel György:}

\section{Terepszemle: Tanulmányok és feljegyzések az infokommunikációs világról}

\author{
Typotex Kiadó, 2012
}

Napjaink médiakommunikációjának egyik leggyakrabban használt fogalma az innováció, korunkat szokták „innovációs társadalom” néven is emlegetni és a társadalom és gazdaság minden problémájának megoldását új termékek és szolgáltatások létrehozásának és elterjesztésének útján keresni. Az innováció mindenhatóságába vetett hit egyik példájaként idézhetjük Neelie Kroes-nak, az Európai Bizottság infokommunikációért (is) felelős alelnökének azt a - nyelvújítónak is tekinthetô - megfogalmazását, hogy „innováljuk ki” magunkat a világban tapasztalható válságból ${ }^{1}$.
Tekintettel az informatikának és a távközlésnek modern világunkban betöltött meghatározó szerepére, nem meglepó, hogy az innovációk jelentôs részével is ezeken a területeken találkozunk. Hajlamosak vagyunk az innovációt elsősorban „technológiai" szempontból nézni és a kutatásfejlesztés-innováció lánc utolsó elemének tekinteni, aminek az előmozdítása elsôsorban a kutatásra (és fejlesztésre) fordítandó pénzügyi és emberi erőforrások növelése útján érhetô el. Ennek eredményeképpen nagyszámú új termék és szolgáltatás jön létre (illetve a meglévốk hatékonysága növekszik), amitól elvárható, hogy az életünk minőségének javítását fogja eredményezni minden területen.

Az innovációs jelenségek természetének a fentiekben leírt „technokrata” szemléleten túlmenő elemzése azonban azt mutatja, hogy az innovációk hatásának érvényesüléséhez nem elegendő az új termékeket és szolgáltatásokat létrehozó kutatás-fejlesztési eredmények megléte, hanem ezeknek a társadalom és gazdaság különböző folyamataiba való beágyazásához jelentôs további - helyenként ellentmondásoktól sem mentes - tevékenységek szükségesek. Ezt úgy is elmondhatjuk, hogy az innováció kutatás-fejlesztési frontvonala mögött jelentős társadalmi-gazdasági hátország helyezkedik el. Bőgel György Terepszemléje ennek a hátországnak a feltérképezésére vállalkozik, az infokommunikációs világ innovációinak vonatkozásában.

Ezt a célt a könyv elsô részében négy tanulmány szolgálja. Közülük az első az innovációnak azzal a - közgazdaságtani szakirodalomban „kreatív rombolás"'-nak nevezett - általános tulajdonságával foglalkozik, hogy valamilyen új dolognak a megjelenése általában együtt jár valami másnak a háttérbe szorulásával, a meglévő dolgok, erốk és szereplôk valamiféle átrendeződésével, ami természetes módon nem tud konfliktusok nélkül végbemenni. Az innováció ilyen alapon kidolgozott elméletének egyes megállapításait illusztrálva, a tanulmányban bőségesen találunk példákat az infokommunikáció területén a közeli és távoli múltban 